\title{
Job quality, job satisfaction and services in Spain
}

\author{
Diego Dueñas Fernández \\ Carlos Iglesias Fernández \\ Raquel Llorente Heras
}




\author{
DIRECTOR \\ Dr. D. Tomás Mancha Navarro \\ Catedrático de Economía Aplicada, Universidad de Alcalá \\ DIRECTOR FUNDADOR \\ Dr. D. J uan R. Cuadrado Roura \\ Catedrático de Economía Aplicada, Universidad de Alcalá
}

AREAS DE INVESTIGACIÓN

ANÁLISIS TERRITORIAL Y URBANO

Dr. D. Rubén Garrido Yserte

Profesor Titular de Universidad

Universidad de Alcalá

ECONOMÍA LABORAL

Dr. D. Carlos I glesias Fernández

Profesor Contratado Doctor

Universidad de Alcalá

ESTUDIOS SECTORIALES, FINANCIEROS Y PYME

Dr. D. Antonio García Tabuenca

Profesor Titular de Universidad

Universidad de Alcalá

SERVICIOS E INNOVACIÓN

Dr. D. Luis Rubalcaba Bermejo

Catedrático de Economía Aplicada

Universidad de Alcalá 


\section{WORKI NG PAPERS}

The Institute of Social and Economic Analysis - IAES (before Servilab) edits Working Papers, where are included advances and results of some research projects done as part of the research done by the Institute's staff and other researchers in colaboration with the Institute.

Those Working papers are available in:

http://www.iaes.es/iuaes_sp/publicaciones.htm

I SSN: $1139-6148$

\section{LATEST WORKI NG PAPERS}

WP-12/ 09 LA EVI DENCI A DEL CAMBI O CLI MÁTI CO. LA NECESI DAD DE LAS POLÍ TI CAS ECONÓMI CAS PREVENTI VAS

Cristina García Fernández

WP-01/ 10 TENDENCI AS DE LOS SISTEMAS I MPOSI TI VOS EN LA OCDE: ESPECI AL REFERENCI A AL CASO ESPAÑOL

José M. Domínguez Martínez

WP-02/ 10 THE REGION OF MADRI D: EFFECTS OF AGGLOMERATION VS. CENTRALISATION.

Carlos Iglesias Fernández, Raquel Llorente Heras y Diego Dueñas Fernández

WP-03/ 10 CONSECUENCIAS DEL ESFUERZO DE CONVERGENCIA NOMI NAL PARA EL CONJ UNTO DE LA ECONOMÍ A ESPAÑOL.

Antonio Torrero Mañas

WP-04/ 10 TECHNI CAL EFFI CI ENCY AND VALUE CHAIN OF EASTERN EUROPEAN UNION COMPANIES: AN EMPI RI CAL APPLICATI ON USI NG SEMI -PARAMETRIC FRONTIER METHODS

Daniel Sotelsek y Leopoldo Laborda

WP-05/ 10 LA DIRECCIÓN DE LA INFORMACIÓN COMO EJE DE LOS GOBIERNOS CORPORATI VOS: I NFORMACI ÓN ASI MÉTRI CA Y LA DIFUSIÓN DE CONTENI DOS EN I NTERNET DE EMPRESAS COTIZADAS. Fernando Javier Crecente Romero

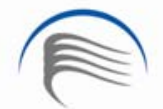

INSTITUTO UNIVERSITARIO de Análisis Económico y Social

Plaza de la Victoria, 2. 28802. Alcalá de Henares. Madrid - Telf. (34)918855225

Fax (34)918855211 Email: iaes@iaes.es. WEB: www.iaes.es 


\title{
JOB QUALITY, JOB SATISFACTION AND SERVICES IN SPAI N
}

\begin{abstract}
Usually, labour market has been evaluated from a quantitative point of view. But nowadays, a new interest stress on quality of job and job satisfaction. Related with this last perspective, a frequent hypothesis that is used for explain the aggregate evolution of job quality establish that the growth of service employment is connected with the increase in the number of low skilled jobs or bad paid. In this context, the paper tries to get a twice objective. First, check the hypothesis that the job quality levels of services are lower than ones observed at the rest of de economy. Second, know if relevant differences among services activities exist in term of job quality. Our analysis use a double perspective to measure a job quality: one based on characteristics of job and other that is laid on worker perception of job. Results point out that services have not de lower quality job levels. Contrary, worker in services activities report higher job satisfaction levels. However, we conclude that into services there is an important heterogeneity by branches in term of job quality. Services and no services share job satisfaction components. So, the observed differences in job satisfaction are sustained rather on differences into the characteristics and conditions of jobs more than into worker's perceptions.

Keywords: J ob quality, job satisfaction, services, ECVT.
\end{abstract}

\section{RESUMEN:}

Habitualmente, el mercado de trabajo ha sido evaluado desde un punto de vista cuantitativo. Sin embargo, actualmente existe un nuevo interés en la calidad del empleo y la satisfacción en el trabajo. En relación con esta última perspectiva, una hipótesis frecuentemente utilizada para explicar la evolución agregada de la calidad del empleo supone que el crecimiento del empleo en los servicios implica el incremento en el número de trabajos poco cualificados o mal pagados. En este contexto, el trabajo trata de conseguir un doble objetivo. Primero, comprobar la hipótesis de que los niveles de calidad del empleo en las actividades de servicios son menores que los observados en el resto de la Economía. Segundo, conocer si existen diferencias relevantes entre las distintas actividades de servicios en términos de calidad del empleo. Los resultados alcanzados señalan que los servicios no presentan menores niveles de calidad en su empleo. Por el contrario, los trabajadores ubicados en actividades de servicios reportan mayores niveles de satisfacción laboral. Sin embargo, se concluye como dentro de las ramas de servicios hay una importante heterogeneidad. Las actividades de servicios y no servicios comparten los mismos componentes en la determinación de su satisfacción laboral, por lo que las diferencias observadas desde esta perspectiva se sustentan en diferencias en las características y condiciones de los trabajos antes que en las percepciones de los trabajadores.

\section{AUTHORS:}

DIEGo DuEÑAS-FERnÁNDEZ. Fundamentals of Economics. Universidad de Alcalá; Institute for Economic and Social Analysis (IAES). diego.duenas@uah.es

CARLOS IGLESIAS-FERNÁNDEZ. Applied Economy Department. University of Alcalá; Institute for Economic and Social Analysis (IAES).carlos.iglesias@uah.es

RAQuel LlORENTE-HERAS Economic Analysis: Economic Theory and Economic History. Universidad Autónoma de Madrid; Institute for Economic and Social Analysis (IAES). raquel.llorente@uam.es) 


\section{NDEX}

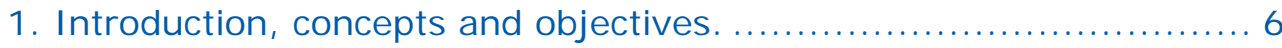

2. Sectoral job quality from an objective perspective. $\ldots \ldots \ldots \ldots \ldots \ldots \ldots 8$

3. The job quality from a subjective perspective $\ldots \ldots \ldots \ldots \ldots \ldots \ldots \ldots \ldots$

4. Job components setting job satisfaction. ...........................22

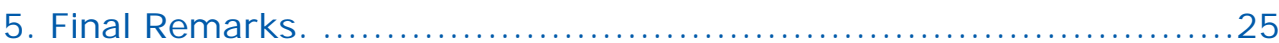

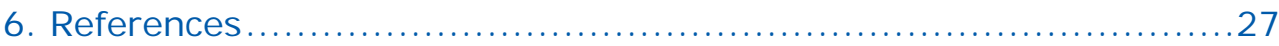

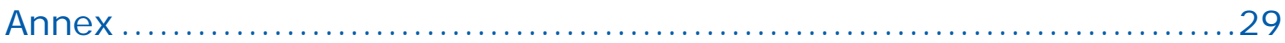




\section{I NTRODUCTION, CONCEPTS AND OBJ ECTI VES.}

$\mathrm{n}$ the last decades, labour market has been mainly evaluated from a quantitative point of view. Mass unemployment, at the economic crisis, and adjustment capacity of labour market, at the economic growth, were the questions more frequently analysed by labour literature. This perspective, which we still can observe, is changing to a more qualitative point of view. New interest stress on quality of job and job satisfaction, concepts that progressively are increasing its relevance as goals of Labour Policy. Interest of policy-marker (MTAS, 2005) prove the relevance of this new perspective, which is expressed both from national (Ley de Igualdad Efectiva entre Mujeres y Hombres that recently has been passed in Spain) and international point of view (the Lisbon Strategy, which was sing in 2000 underline job quality as a main goals from EU in 2010) ${ }^{1}$.

According with present literature, and refusing the idea that wages include all labour aspects that are related with job quality (compensating wage differentials neoclassical hypothesis), job quality must be considered like a multidimensional question (Bonhomme y Jolivet, 2005), from different aspect that are involved and perspectives (macro and micro), in one side, and agents who are implicated (workers and companies), in the other. Then, first task we must affront when we deal with job quality is to set its definition.

First, from a microeconomic point of view and connected with workers position, job quality is expressed by the job satisfaction that worker perceive in relation with characteristics that make up their labour relation. Following main results reach by economic literature, the most relevant characteristics setting worker's job satisfaction are some like that (Warr, 1999; Hamermesh, 2001, Ahn y García, 2004, Ahn, 2005, ):

a. Working time and flexibility related with this matter.

b. Wage earned and other kind of complementary earnings.

c. Safety at work.

Furthermore, some studies add other psychological and sociological variables, like social relationship carry out at working place, the effort, prestige, independence and the existence of labour career (Clark, 2005).

Otherwise, from the microeconomic perspective of companies, job quality is mainly related with two very important variables: competitiveness and flexibility. Nowadays, companies must deal with economic contexts defined by more and more globalized markets, with an increasing instability and uncertainty of product demand, the

${ }^{1}$ European Commission (2008). 
requirement of innovation and an accelerated diffusion of new technology of information and communication. Then, companies have to confront a growing need to get flexibility into theirs production processes and work, trying to get the competitiveness that is required by a progressively more complex markets (Ducatel, 1994; Fagerberg, 1996; Fagerberg, Srholec y Knell, 2004).

Second, and from a macroeconomic point of view, the papers are focused on to analyse the evolution of job quality in consequence of the influence of several factors like qualifications and skills of working population, the behaviour of productivity, the processes of technological diffusion, the evolution of wages and changes in sectoral composition of employment.

Related with this last perspective, a frequent hypothesis that is used for explain the aggregate evolution of job quality establishing that, in general term, the growth of service employment is connected with the increase of the number of low skilled jobs or bad paid. Then, in some extent the tertiarization would be related with a decreasing in the aggregated level of job quality (Houseman, 1995).

If we pay attention to evolution of employment in services in Europe during last decades, we send out a strong expansion of this kind of employment covering all countries. In this context, the tertiarization levels of Luxemburg ( 80 per cent) or France, Holland and Belgium (with percentages over 70 per cent) are especially intense ${ }^{2}$. Spain shares this evolution, although employment in services only weigh 66 per cent over the all employment, that is only higher that percentage showed by Portugal, Italy and Greece. Any way, in the last economic expansive period, the services activities have been an highest expansion in Spain, only bellow construction activities.

Otherwise, there are clues that Spanish economy has some problems related with job quality. This sense, we must point out the high and persistent temporary rates (Toharia, 2005), their lower productivity levels of Spanish productive structure (Maroto y Cuadrado, 2006) or the worrying labour injury levels (Hernanz y Toharia, 2004).

Maybe, these facts can get a job quality worse in Spain and this pattern could be related with the increase of employment into services sector. However, the analysis carried out about job quality by sectors use to consider services only from an aggregated definition. So, we don't know if each different activity that make up services present similar pattern in job quality term or not.

From previous arguments, our paper tries to get a twice objective. First, check the hypothesis that the job quality levels of services activities are lower than ones observed at the rest of de economy. Second, know if

\footnotetext{
2 Date year 2007.
} 
relevant differences among services activities exist in term of job quality.

In order to get it, paper uses a double perspective to measure the job quality: one based on characteristics of job (objective perspective), and other that is laid on worker perception of job (subjective perspective).

Paper is organized following the next structure. In section two is estimated a job quality index by sectors in order to compare this concept for the main different sectors (job quality from a objective point of view) and into service branches. Then, we carry out an analysis of job satisfaction by sectors (job quality from a subjective perspective). Finally some ordered probits models are estimated trying to identify the relation linked between job satisfaction and the main aspects of job.

Dates used come from Spanish Labour Conditions Survey (Encuesta de Condiciones de Vida en el Trabajo, ECVT), second quarter to 2007, that is elaborated by Ministerio de Trabajo e Inmigración (MTIN).

\section{SECTORAL J OB QUALITY FROM AN OBJ ECTI VE PERSPECTIVE.}

$\mathrm{n}$ order to measure the job quality, we have estimated an index using information of 12 characteristics of jobs. Theses variables (box

1 ) try to approach the main aspect frequently used into economic literature (Green, 2006, European Commission, 2009) and take into account the available statistical data.

Box 1.

Job Quality from an objective perspective. Characteristics of job.

\begin{tabular}{|l|}
\hline Overall job satisfaction level (1) \\
\hline Annual net earning by worker (Euros) (2) \\
\hline Frequency of working time extend (3) \\
\hline Labour promotion possibility into company (4) \\
\hline Risk level o danger at work (5) \\
\hline Labour relationship between manager and employees (6) \\
\hline Routine level at work (7) \\
\hline Stress level at work (8) \\
\hline Motivation level at work (9) \\
\hline Confidence level with manager, colleague and subordinates at work (10) \\
\hline Skill match at work (11) \\
\hline Labour training paid by company (12) \\
\hline
\end{tabular}

Source: Own elaboration from ECVT-2007. MTIN.

In order to measure job quality we will estimate a synthetic index using theses pool of variables. Then, we have to set how aggregate data, 
because heterogeneity of unit used for different variables. So, according with methodology have been used in previous studies (Toharia y Caprile, 2006, European Commission, 2009), first we obtain data for each variable mentioned. Then, we calculate the average and standard deviation of each variable using a sectoral approach. Next, the variables are typified into normalised values ( $z$ variables). This way, if a sector shows a positive value in any variable we know that this labour aspect in this sector has been evaluated upper than average and it has a positive contribution to job quality into this sector. The contrary conclusion must be got if we see a negative value. This way, each sectoral value always must be interpreting in relative term related to the others sector. Of course, in function of nature of labour aspect analysed, our variables goes into index with positive or negative values, if increasing or decreasing job quality. In our case, variables number 1, 2, 4, 6, 9, 10, 11 y 12 have a positive contribution to final job quality, but we suppose that variables number 3, 5, 7 y 8 have a negative influence in final job quality. In the last, final value of synthetic index is the result of a weighted average of all variables. Weights reflecting our opinion about the relative importance of variables on job quality. Theses weights are the next ones:
$\checkmark \quad 1 / 6$ for variables numbers 1 y 2 .
$\checkmark \quad 1 / 12$ for variables numbers $3,5,6,9,10$ y 11 .
$\checkmark \quad 1 / 24$ for variables numbers $4,7,8$ y 12 .

We make up the job quality synthetic index first for the four main sector (Agriculture, Industry, Construction and Services) and then for the great activities of services (ICSERV): Trade and Repair Services; Accommodation and Food Services Activities; Transportation, Storage and Communications; Financial and Insurance Activities; Real State and Business Services; Public Administration; Education; Human Health and Social Work Activities; Personal Services and Household as Employer ${ }^{3}$.

TABLE 1.

J ob Quality I ndex for the main activity sectors. (Source: Own elaboration from ECVT-2007. MTEI).

\begin{tabular}{|l|c|c|c|c|c|c|c|c|c|c|c|c|c|}
\hline & {$[1]$} & {$[2]$} & {$[3]$} & {$[4]$} & {$[5]$} & {$[6]$} & {$[7]$} & {$[8]$} & {$[9]$} & {$[10]$} & {$[11]$} & {$[12]$} & I CSERV \\
\hline Agriculture & $-1,43$ & $-1,21$ & 1,32 & $-1,28$ & $-0,22$ & 0,82 & 0,65 & $-1,42$ & $-0,70$ & $-0,71$ & 0,96 & $-1,39$ & $-\mathbf{0 , 5 8}$ \\
\hline Industry & 0,20 & $-0,43$ & $-1,07$ & $-0,32$ & $-0,34$ & $-1,33$ & 0,81 & 0,37 & $-1,02$ & $-0,92$ & $-0,77$ & 0,67 & $-\mathbf{0 , 2 9}$ \\
\hline Construction & 0,33 & 0,79 & $-0,32$ & 0,77 & 1,44 & 0,72 & $-1,38$ & 0,14 & 0,87 & 1,22 & 0,76 & $-0,06$ & $\mathbf{0 , 4 7}$ \\
\hline Services & 0,90 & 0,85 & 0,07 & 0,83 & $-0,88$ & $-0,21$ & $-0,07$ & 0,91 & 0,85 & 0,41 & $-0,95$ & 0,78 & $\mathbf{0 , 4 0}$ \\
\hline
\end{tabular}

\footnotetext{
${ }^{3}$ Sectoral aggregation is explained at annex.
} 
From a aggregate point of view (table 1 ) it's possible to conclude that there are two sector with job quality levels over the average: Construction and Services, and others two activities below: Industry and Agriculture.

In the case of Construction, workers consider that it's a dynamic sector, with low levels of routine, and a high level of confidence both with colleague, manager and subordinates. What's more, motivation at work and salary earned are variables that also obtain a high outcome. In the other side, in Services overall satisfaction, motivation at work and wages point out over the all variables.

Opposite, Industry is the activity where working time extend is more probably and motivation at work is the lowest. Finally, Agriculture, although workers use to show the lowest stress at work levels, it's an economic activity with few overall job satisfaction and scarce training.

However, we must remind that synthetic index we have build use typified values. Then results only inform about relative job quality rather than absolute levels of quality. Then, it's possible that Industry, for example, have an acceptable job quality level but this level was lower that the observed in other activity sectors.

In the end, conclusion must be that data not permit to say that services were defined by to own a relative bad job quality. Any way, we are conscience that synthetic index we have calculate use only a few and specific service branches in order to approach job quality. Then outcomes have been reach can be discussed ${ }^{4}$.

From this preliminary study, table 2 carries out a deep analysis job quality in Services, considering its main activity components.

\footnotetext{
${ }^{4}$ Iglesias, Llorente y Dueñas (2009) calculate a close index but using a wide range of information (49 variables). Outcomes that was similar, in the sense that Services are not the worst economic activity from a job quality perspective.
} 
TABLE 2.

J ob Quality I ndex for main branches of Services.

\begin{tabular}{|l|c|c|c|c|c|c|c|c|c|c|c|c|c|}
\hline & {$[1]$} & {$[2]$} & {$[3]$} & {$[4]$} & {$[5]$} & {$[6]$} & {$[7]$} & {$[8]$} & {$[9]$} & {$[10]$} & {$[11]$} & {$[12]$} & I CSERV \\
\hline $\begin{array}{l}\text { Trade and Repair } \\
\text { Services }\end{array}$ & $-0,40$ & $-0,69$ & 0,89 & $-0,07$ & $-0,46$ & 0,85 & 0,32 & $-0,63$ & 0,18 & 0,37 & 0,22 & $-0,62$ & $-\mathbf{0 , 1 0}$ \\
\hline $\begin{array}{l}\text { Accommodation and } \\
\text { Food Services } \\
\text { Activities }\end{array}$ & $-1,12$ & $-0,71$ & 1,27 & 0,01 & $-0,67$ & 1,41 & 1,45 & 0,34 & 0,95 & $-0,32$ & 0,18 & $-1,21$ & $-\mathbf{0 , 2 9}$ \\
\hline $\begin{array}{l}\text { Transportation, } \\
\text { Storage and } \\
\text { Communications }\end{array}$ & $-0,33$ & 0,21 & 0,10 & $-0,67$ & 1,69 & $-0,01$ & 1,36 & 0,94 & $-1,66$ & 0,40 & 0,31 & $-0,44$ & $-\mathbf{0 , 3 9}$ \\
\hline $\begin{array}{l}\text { Financial and } \\
\text { Insurance Activities }\end{array}$ & 1,02 & 2,31 & 0,28 & 2,58 & $-0,83$ & 0,22 & $-0,51$ & 1,32 & 1,22 & 1,43 & $-1,56$ & 1,33 & $\mathbf{0 , 8 4}$ \\
\hline $\begin{array}{l}\text { Real State and } \\
\text { Business Services }\end{array}$ & $-0,55$ & 0,32 & $-0,04$ & $-0,19$ & $-0,50$ & $-0,23$ & $-0,11$ & 0,06 & 0,19 & $-0,85$ & 0,10 & $-0,34$ & $-\mathbf{0 , 0 8}$ \\
\hline \begin{tabular}{l} 
Public Administration \\
\hline Education
\end{tabular} & 0,49 & $-0,48$ & $-1,59$ & $-0,13$ & 0,94 & $-1,51$ & $-0,53$ & $-1,03$ & $-1,18$ & $-0,25$ & $-1,21$ & 1,06 & $-\mathbf{0 , 1 8}$ \\
\hline $\begin{array}{l}\text { Human Health and } \\
\text { Social Work Activities. }\end{array}$ & 0,10 & 0,37 & $-0,93$ & $-0,44$ & 1,26 & $-1,58$ & $-0,28$ & 0,44 & $-0,61$ & $-0,27$ & 1,28 & 0,68 & $-\mathbf{0 , 0 5}$ \\
\hline $\begin{array}{l}\text { Personal Services and } \\
\text { Household as } \\
\text { Employer }\end{array}$ & $-1,13$ & $-1,04$ & $-1,02$ & $-0,65$ & $-0,91$ & 0,27 & 0,11 & $-1,85$ & $-0,10$ & $-1,76$ & $-0,67$ & $-1,32$ & $\mathbf{- 0 , 4 0}$ \\
\hline
\end{tabular}

Source: Own elaboration from ECVT-2007. MTIN.

Data show that there are two sector with higher job quality levels: Financial and Insurance Activities $(0,84)$ and Education $(0,65)$. Opposite, Personal Services and Household as Employer $(-0,40)$; Transport, Storage and Communication (-0,39); and Accommodation and Food Services Activities $(-0,29)$ stand out below the rest. With job quality levels around the average we find Public Administration $(-0,18)$, Trade and Repair $(-0,10)$; Real State and Business Services $(-0,08)$; and Human Health and Social Work $(-0,05)$.

If we pay more attention to table 2 , is worth to carry out an analysis both by columns and rows. From the first perspective, we can set a sectoral ranking for each variable included in the index making possible to underline the next paths:

$\checkmark$ Related with overall job satisfaction perceived by workers, the best service activities are Education $(1,90)$ and Financial and Insurance Activities $(1,02)$, while the worst are to Accommodation and Food Services Activities $(-1,12)$ and Personal Services and Household as Employer $(-1,13)$.

$\checkmark$ If we observe annual net wages per workers, Financial and Insurance Activities $(2,31)$ have very higher level that others, and Accommodation and Food Services Activities $(-0,71)$ and Personal Services and Household as Employer $(-1,04)$ have the low value for this category. 
$\checkmark \quad$ Frequency of working time extend is especially negatively related with Accommodation and Food Services Activities $(1,27)^{5}$ and Education $(1,03)$, but it is probable that a different reason was explaining this results. In the first, it would express working conditions per se, and in Education this outcome is related with teacher possibility of check exam and other tasks at home. In the other side, the more positive values are associated with Public Administration $(-1,59)$ and Personal Services and Household as Employer $(-1,02)$.

$\checkmark$ Labour promotion into the company are more probable in Financial and Insurance Activities $(2,58)$. The lowest levels are observed in two sectors: Transport, Storage and Communications; and Personal Services and Household as Employer. Then, patterns are very close to the situation observed when we consider wages or overall job satisfaction, underlining the remarkable importance of Financial and Insurance Activities in term of job quality.

$\checkmark$ The poorest outcomes from risk level o danger at work are to Transport, Storage and Communication $(1,69)^{3}$ and Human Health and Social Work Activities $(1,26)$, and the more positive situation is observed into Personal Services and Household as Employer ($0,91)$ and Financial and Insurance Activities $(-0,83)$.

$\checkmark$ Accommodation and Food Services Activities $(1,41)$ and Trade and Repair $(0,85)$ are the best services branches in term of personal relationship at work, and Human Health Activities and Social Work $(-1,58)$ and Public Administration $(-1,51)$ show the worst value for this variable. It could be conclude that activities with less qualification, where the social and professional relation are frequent and with a higher contact with customers, reach worst result into this job quality component.

$\checkmark$ Routine level at work is more important in Accommodation and Food Activities Services $(1,45)^{6}$ and Transport, Storage and Communication $(1,36)$. In opposite way, Education $(-1,81)$ and Public Administration $(-0,53)$ would be related with the most dynamic work.

$\checkmark$ Stress at work have a more relative importance in Financial and Insurance Activities (1,32) and Transport, Storage and Communication $(0,94)$. Contrary, the most relaxed activities are Personal Services and Household as Employer $(-1,85)$ and Public Administration $(-1,03)$.

$\checkmark$ Financial and Insurance Services $(1,22)$ and Education $(1,01)$ stand out by its motivation at work, while Transport, Storage and

\footnotetext{
${ }^{5}$ Remember that this variable is negative weighing in the index.

${ }^{6}$ Remember that this variable is negative weighing in the index..
} 
Communication $(-1,66)$ and Public Administration $(-1,18)$ have the poorest result from this perspective.

$\checkmark$ If we attend to confidence level at work, two activities are over the rest: Financial and Insurance Services $(1,43)$, and Education $(1,26)$. In the opposite side, we would find Personal Services and Household as Employer $(-1,76)$ and Real State and Business Services $(-0,85)$.

$\checkmark \quad$ The best match between job and worker in term of qualification is observed in Education $(1,35)$ and Human Health and Social Work $(1,28)$. Mismatch in qualification (overeducating) is more frequent in Financial and Insurance Services $(-1,56)$ and Public Administration $(-1,21)$.

$\checkmark$ Finally, regarding companies doing specific training for workers, this situation is frequent in Financial and Insurance Services $(1,33)$ and Public Administration $(1,06)$. This kind of training is lower in Personal Services and Household as Employer $(-1,32)$ and Accommodation and Food Activities Services $(-1,21)$.

If we analyse table 2 by row we can establish a job quality composition patterns for every services activity. In order to do it, we present next figures numbers 1,2 and 3 , when we can see and compare the contribution of each component to final job quality outcome by sector.

\section{FIGURE 1.}

Job Quality Index Composition. Trade and Repair; Accommodation and Food Activities Services; Transport, Storage and Communication.
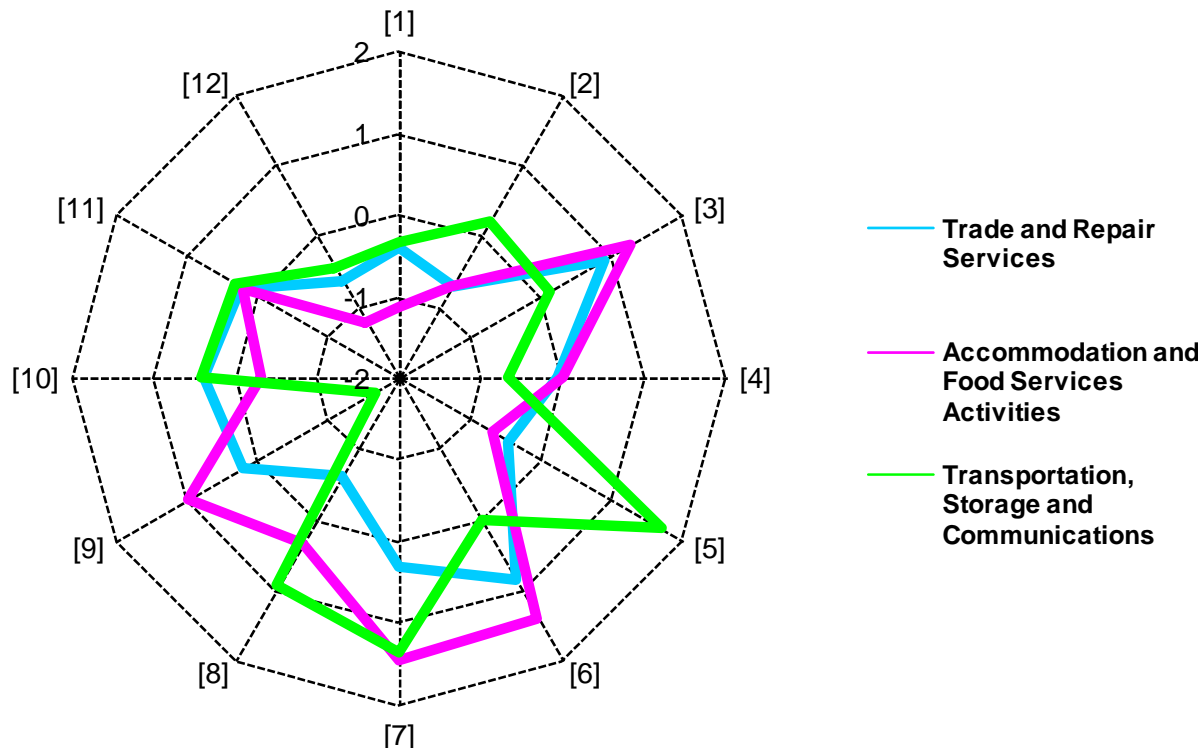

Source: Own elaboration from ECVT-2007. MTIN 
FIGURE 2.

J ob Quality I ndex Composition. Financial and I nsurance Services; Real State and Business Services; and Public Administration.

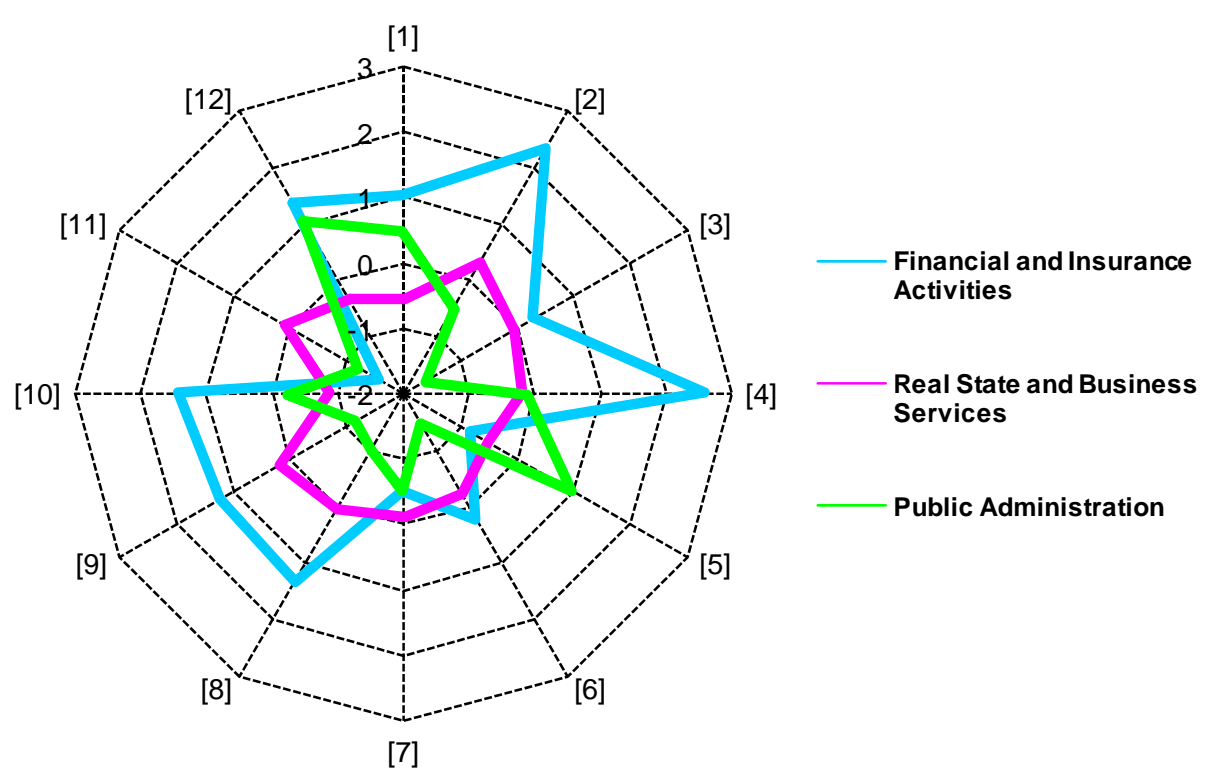

Source: Own elaboration from ECVT-2007. MTIN.

Trade and Repair show especially positive outcomes in social relationship at work, although working time extend is a frequent situation. Close to previous activity, Accommodation and Food Activities Services also show a good situation attending to personal relationship at work, but routine is also frequent. Transport, Storage and Communication stand out by positive confidence level at work, but risk level is notoriously higher.

Financial and Insurance Services show the best job quality index of the all activities, from good contribution of labour promotion possibilities, that closely related with wages, although in some extent worker in this kind of activity consider that mismatch (overeducating) is a frequent situation. Real State and Business Services has intermediate value for all job quality components. Any way, risk at work may be the best component, and confidence at work perhaps the worst. In Public Administration it is not frequent to extend working time but labour relationship gets no good outcomes. 
FIGURE 3.

J ob Quality I ndex Composition. Education, Human Health and Social Work; Personal Services and Household as Employer.

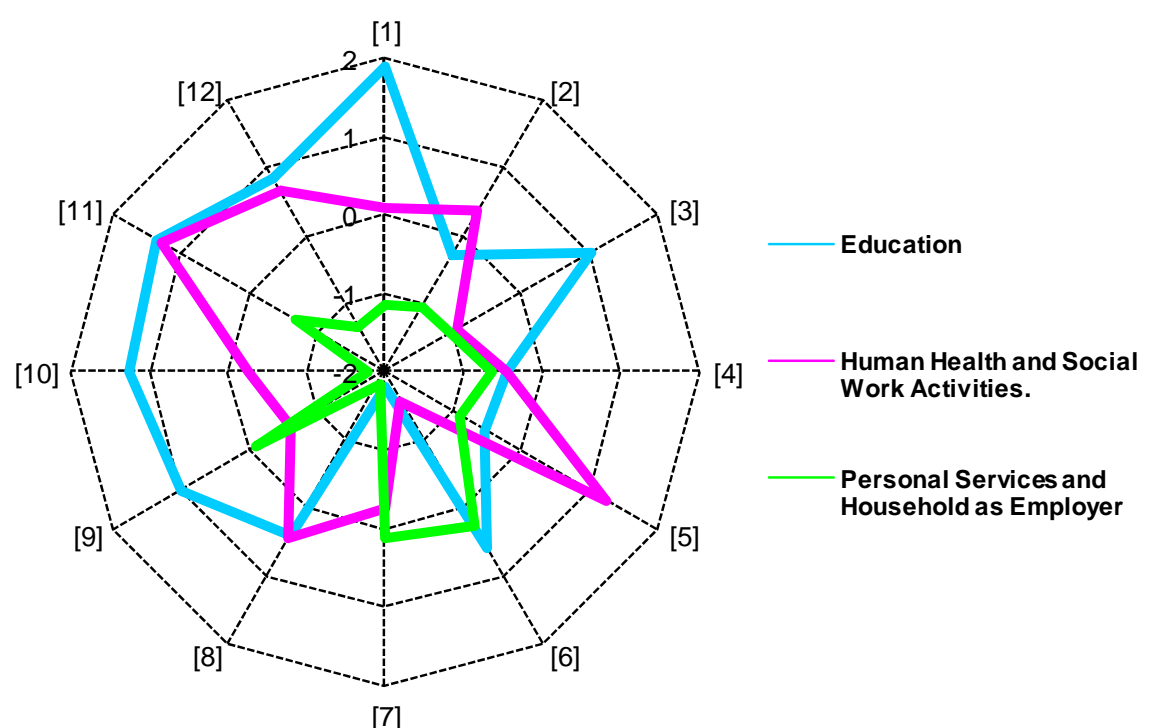

Source: Own elaboration from ECVT-2007. MTEI.

Education stand out values of overall job satisfaction (positive) and working time extend (negative). Workers in Human Health Services and Social Work perceive a high educational matching at work but they thing that labour relationship are no the best aspect of their jobs. And last, Personal Services and Household as Employer, the sector with the lowest job quality index value of the service sector, stand out stress level at work, that is very low, and opposite the existence of a few level of confidence at work, both with colleagues and managers.

Finally, and from an objective perspective (based on characteristics of job), main conclusion must be that is not truth that Services have lower relative levels of job quality (bad jobs). Contrary, and according with variables we have used in order to measure the quality of job, Services own overall higher levels than Industry. If we break up our analysis considering main services activities, the conclusion must be heterogeneity. However, the best service activities would clearly be Financial and Insurance Services, in one side, and Education, in the other, with job quality index levels upper the average value. 


\section{THE J OB QUALITY FROM A SUBJ ECTIVE PERSPECTIVE.}

$\mathrm{N}$ ow, in this section we are going to analyse job quality from a subjective perspective. So, we will use data related with worker perception of their job. This involve that now analysis turn round the concept of job satisfaction, and again strategy will be compare situation in Services with the rest of employment. We will also try to look into its determinants.

Following theses objectives, figure number 4 show the levels of job satisfaction declared by workers. We distinguish among the four main sector and services activities.

We can see that Services is the economic activity where worker say to have a higher job satisfaction, showing 7,29 as average score (over 10). Opposite, Agriculture have the lowest levels of job satisfaction ${ }^{7}$. However, there are important differences into services activities, with a wide range of job satisfaction levels from 6,96 (Accommodation and Food Activities Services) to 7,85 (Education).

Which are the determinants of these job satisfaction levels? Figure number 5 breaks up the previous information considering different aspects included into ECVT-2007 database, both for main sector and services activities. Now, we include the next components of job satisfaction:

- Wage.

- Working time.

- Working time flexibility.

- Rest at work.

- Holidays.

- Job security.

- Good labour relationship at work.

- $\quad$ Kind of work that is carried out.

- Physical environment.

- Health and risk at work.

- Training possibility by companies.

\footnotetext{
${ }^{7}$ It's worth to be mentioned that the sectoral ranking that we obtain when we measure job quality from a subjective perspective result very close to the previously obtained from a objective point of view.
} 
- No wage earnings.

- Work organization.

- Autonomy at work.

- Participation possibilities at work.

- Labour promotion.

- Manager evaluation.

- Personal development.

From a general point of view, job satisfaction reach its higher values for components like labour relationship at work, the kind of work that is carried out, autonomy and job security. Contrary, the components with a lower value are no wage-earnings, training possibilities by companies and labour promotion.

FIGURE 4.

J ob Satisfaction levels by main activity sector and components of Services.

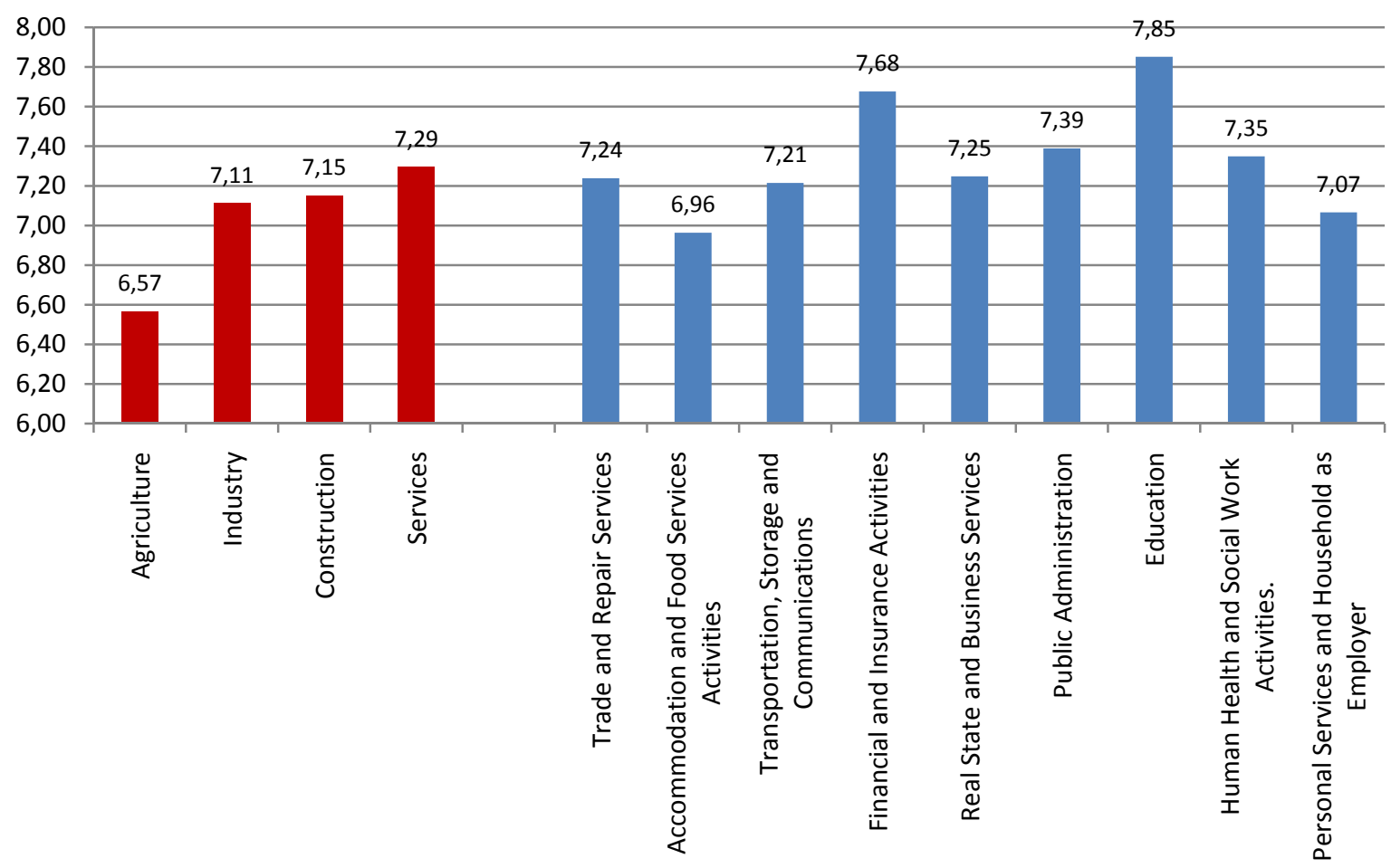

Source: Own elaboration from ECVT-2007. MTIN. 
The higher job satisfaction that we previously concluded for Services is based on values levels that are higher for every component. If we pay attention to figure 5, we can see as Service's workers always report higher values that the rest of employees, for every one of labour aspects considered.

Higher differences in job satisfaction between Services and no-Services employment are focused on holidays, job security and no wage earnings. Opposite, the differences get narrow for wages, rest at work and personal development.

Then, if job satisfaction is a good proxy of job quality, now we know that job quality in Services is higher from a better labour relationship at work, the kind of tasks that are carry out, the job security and the level of autonomy that exists in Services. What is more, difference between Services and no-Services are based on worker perception related with holidays, job security and non salaried components of remuneration.

In order to get a deeper knowledge about theses outcomes, we have estimated a couple of ordered probits model. Our objective is to establish which variables, personal and professional (independent variables) are more closely related with job satisfaction (dependent variable). Estimation have been done for the all employment (table 3) and for employment in Services (table 4). Variables that have been considered like explicative arguments are the next ones:

- Sex.

- Age.

- $\quad$ Level of study.

- Labour occupation.

- Professional Status.

- Wage level.

- Working time.

We also include information about activity sector. This variable has two difference definitions: main four sectors (first model) and nine main kinds of services (second model). Our main objective is to identify how different economic activities show differences in term of job satisfaction, controlling by main personal and professional characteristics of workers. 
FIGURE 5

Job Satisfaction in Service Sector according with different aspects of work

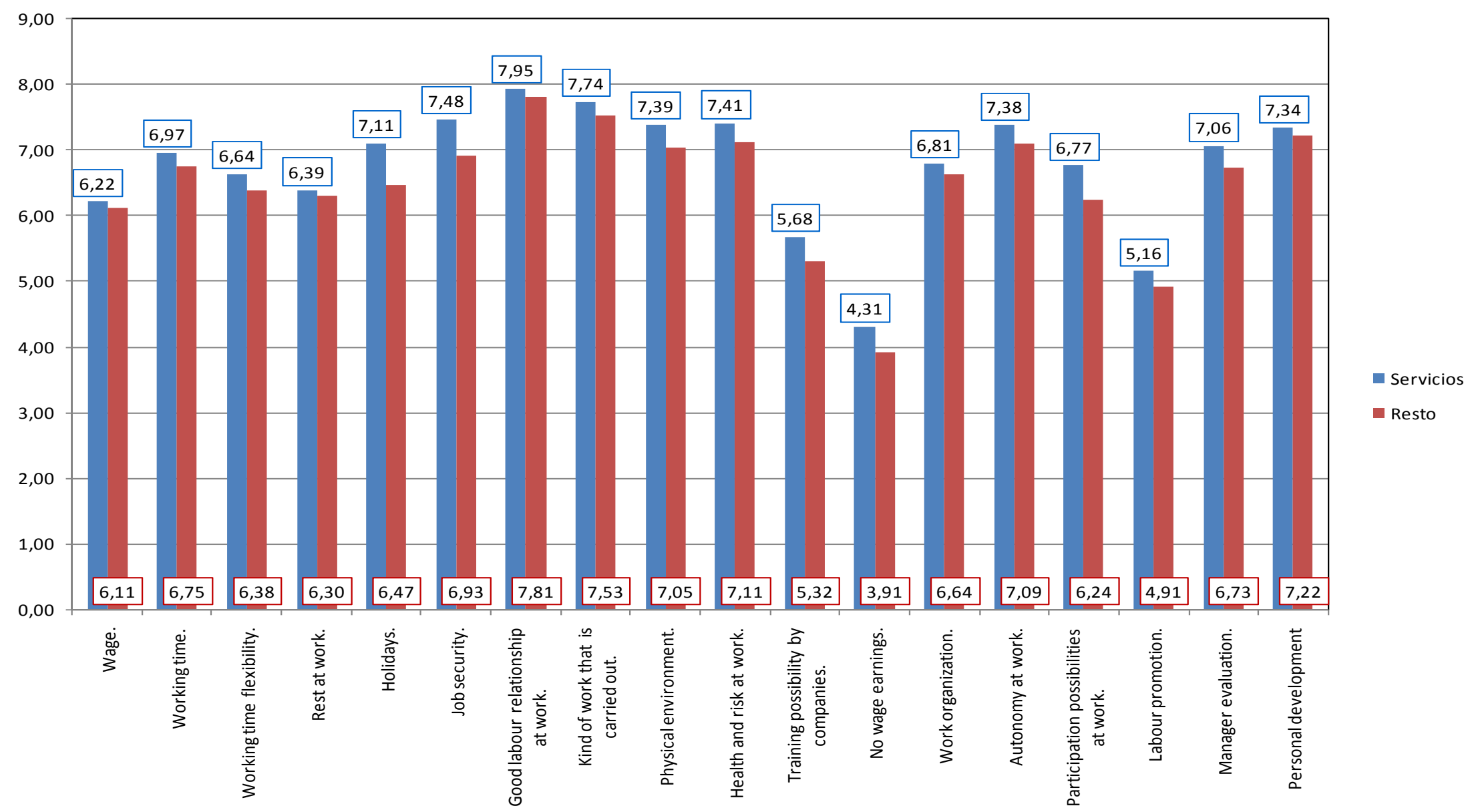

Source: Own elaboration from ECVT-2007. MTIN. 
TABLE 3.

Probability of job satisfaction. All employment.

\begin{tabular}{|c|c|c|}
\hline & Coefficient & Significance \\
\hline Men & $-0,086$ & 0,000 \\
\hline Women & A & . \\
\hline Age: 16 a 29 & 0,049 & 0,000 \\
\hline Age: 30 a 49 & $-0,033$ & 0,000 \\
\hline Age: 50 and more & A & . \\
\hline Primary studies or lower. & 0,139 & 0,000 \\
\hline Compulsory Secondary studies and Vocational Training, first stage & 0,153 & 0,000 \\
\hline Not Compulsory Secondary studies and Vocational Training, second stage & 0,074 & 0,000 \\
\hline University studies & A & . \\
\hline White Collar High Skill & 0,275 & 0,000 \\
\hline White Collar Low Skill & 0,092 & 0,000 \\
\hline Blue Collar High Skill & 0,113 & 0,000 \\
\hline Blue Collar Low Skill & A & . \\
\hline Agriculture & $-0,354$ & 0,000 \\
\hline Industry & $-0,091$ & 0,000 \\
\hline Construction & $-0,098$ & 0,000 \\
\hline Services & A & . \\
\hline Employees & $-0,153$ & 0,000 \\
\hline Not employees & A & . \\
\hline Wages: 1.000 Euros o lower & $-0,411$ & 0,000 \\
\hline Wages: Between 1.001 and 1.200 Euros & $-0,218$ & 0,000 \\
\hline Wages: Between 2.001 and 1.600 Euros & $-0,101$ & 0,000 \\
\hline Wages: More that 1.601 Euros & A & . \\
\hline Full time & 0,162 & 0,000 \\
\hline Voluntary part-time & 0,188 & 0,000 \\
\hline Involuntary part-time & $A$ & . \\
\hline $\begin{array}{ll}\text { Cox y Snell } & 0,051 \\
\text { Nagelkerke } & 0,052 \\
\text { McFadden } & 0,014\end{array}$ & & \\
\hline \multicolumn{3}{|l|}{ A. Reference category } \\
\hline
\end{tabular}

Source: Own elaboration from ECVT-2007. MTIN). 
TABLE 4.

Probability of job Satisfaction. Services.

\begin{tabular}{|c|c|c|}
\hline & Estimation & Significance \\
\hline Men & $-0,078$ & 0,000 \\
\hline Women & A & . \\
\hline Age: 16 a 29 & 0,087 & 0,000 \\
\hline Age: 30 a 49 & $-0,001$ & $0,289 *$ \\
\hline Age: 50 o more & A & . \\
\hline Primary studies or lower & 0,159 & 0,000 \\
\hline Compulsory Secondary studies and Vocational Training, first stage & 0,178 & 0,000 \\
\hline Not Compulsory Secondary studies and Vocational Training, second stage & 0,098 & 0,000 \\
\hline University studies & A & . \\
\hline White Collar High Skill & 0,231 & 0,000 \\
\hline White Collar Low Skill & 0,073 & 0,000 \\
\hline Blue Collar High Skill & 0,246 & 0,000 \\
\hline Blue Collar Low Skill & A & . \\
\hline Trade and Repair & $-0,002$ & $0,059 *$ \\
\hline Accommodation and Food Activities Services & $-0,138$ & 0,000 \\
\hline Transport, Storage and Communication & 0,005 & 0,000 \\
\hline Financial and Insurance Services & 0,193 & 0,000 \\
\hline Real State and Business Services. & 0,017 & 0,000 \\
\hline Public Administration & 0,076 & 0,000 \\
\hline Education & 0,324 & 0,000 \\
\hline Human Health and Social Work Activities & 0,051 & 0,000 \\
\hline Personal Services and Household as Employer & A & . \\
\hline Employees & $-0,117$ & 0,000 \\
\hline Not employees & $A$ & . \\
\hline Wages: 1.000 Euros o lower & $-0,317$ & 0,000 \\
\hline Wages: Between 1.001 and 1.200 Euros & $-0,158$ & 0,000 \\
\hline Wages: Between 2.001 and 1.600 Euros & $-0,046$ & 0,000 \\
\hline Wages: More that 1.601 Euros & 0,000 & . \\
\hline Full time & 0,223 & 0,000 \\
\hline Voluntary part-time & 0,228 & 0,000 \\
\hline Involuntary part-time & A & . \\
\hline $\begin{array}{ll}\text { Cox y Snell } & 0,048 \\
\text { Nagelkerke } & 0,050 \\
\text { McFadden } & 0,013\end{array}$ & & \\
\hline $\begin{array}{l}\text { A. Reference Category } \\
* \text { Not significant at a probability of } 95 \% \text {. }\end{array}$ & & \\
\hline
\end{tabular}

Own elaboration from ECVT-2007. MTIN. 
Estimation for all employment (model 1, table 3 ) point out that women get more job satisfaction than men, as well as young people, workers with medium level of study, working White Collar High Skill and earning the highest wages.

All main sectors have negative and significant coefficients. Taking into account that Services have been included as reference category in the model, this results say us that workers in Services report higher job satisfaction levels than colleagues working in the no-service employment.

Estimation restricted to employment in Services (model 2, table 4) underline the heterogeneity of service activities attending to job satisfaction. Financial and Insurance Service and Education direct to higher levels of job satisfaction, once we control by personal and professional variables. Opposite, Accommodation and Food Activities Services and Trade and Repair show negative coefficients.

\section{J OB COMPONENTS SETTI NG J OB SATI SFACTION.}

A last interesting question may be to find out the determinants of job satisfaction. In other words, our motivation is to establish which job components have a great influence on workers perception of job satisfaction, finding out if there are differences between sectors.

In order to do it, we have estimated a new couple of probability models (Probit ordered) where variable we want to explain is the job satisfaction level reported by worker as consequence of previously mentioned main job components. ${ }^{8}$. Explicative variables are made up defining labour aspects according with previous section:

a. Earning a high wage.

b. Existing possibilities of working time extend.

c. Possibilities of labour promotion.

d. Existence of risk at work or danger.

e. Good labour relationship at work.

f. Routine at work.

g. Existence of stress.

h. High labour motivation.

${ }^{8}$ Clark (2005) carries out a close analysis. 
i. Confidence at work.

j. Adequate qualifications match.

k. Training possibilities in the company.

We have estimated this model according with different strategies. First (model 1) we consider all employment and a variable that difference between services and non-services employment is included. The objective of model 1 is to conclude if working in services is positive or negatively related with job satisfaction. Second (model 2), carry out estimation only for employment in services, and a variable that difference between main kinds of service activities is included. Now, objective is to know if difference services activities have different patterns of relation with job satisfaction. Last (models 3 and 4 ) we estimate both models (all employment and only employment in services) again but without include sectoral variables. Propose is to get comparable estimation in order to indentify the existence of differences in services in term of determinants of job satisfaction.

The results of estimations are in table 5. Main conclusion may be the next ones:

$\checkmark$ For all employment (model 1 ), job satisfaction sharply increase for the effect of a high wage, possibilities of promotion at work and motivation at work. So, these are the components of worker perception more relevant explaining overall job satisfaction reported by workers. Contrary, risk at work, working time extends o labour flexibility direct to less job satisfaction ${ }^{9}$, as well as routine o stress situation.

$\checkmark$ Working in Services is positively related with job satisfaction, but coefficient is very moderate $(0,082)$. Then, controlling by job satisfaction determinants, working in services per se is not a core factor explaining job satisfaction.

$\checkmark$ Models 3 and 4 confirm this outcome. There are very few differences between services and no-services employment in term of job satisfaction determinants. It only can be mentioned the role played by motivation at work, which influence is higher in services that in the rest of employment. Then Services share with the rest of employment job satisfaction determinants. Job satisfaction is determinate from similar components both in Services and in the all employment.

9 Green (2006) reaches a similar conclusion about work intensity. In U.K., technological changes seem be associated with a higher work commitment, increasing labour effort but also job dissatisfaction. 
TABLE 5.

Determinants of J ob Satisfaction.

\begin{tabular}{|c|c|c|c|c|c|c|c|c|}
\hline & \multicolumn{2}{|c|}{ Model 1} & \multicolumn{2}{|c|}{ Model 2} & \multicolumn{2}{|c|}{ Model 3} & \multicolumn{2}{|c|}{ Model 4} \\
\hline & \multicolumn{2}{|c|}{ All Employment } & \multicolumn{2}{|c|}{ Services } & \multicolumn{2}{|c|}{ All Employment } & \multicolumn{2}{|c|}{ Services } \\
\hline & Estimation & Sig. & Estimation & Sig. & Estimation & Sig. & Estimation & Sig. \\
\hline High wage & 0,505 & 0,000 & 0,457 & 0,000 & 0,510 & 0,000 & 0,464 & 0,000 \\
\hline Extend & $-0,115$ & 0,000 & $-0,115$ & 0,000 & $-0,113$ & 0,000 & $-0,120$ & 0,000 \\
\hline Promotion & 0,593 & 0,000 & 0,554 & 0,000 & 0,593 & 0,000 & 0,545 & 0,000 \\
\hline Risks & $-0,192$ & 0,000 & $-0,142$ & 0,000 & $-0,202$ & 0,000 & $-0,120$ & 0,000 \\
\hline $\begin{array}{l}\text { Good labour } \\
\text { relationship }\end{array}$ & 0,319 & 0,000 & 0,297 & 0,000 & 0,321 & 0,000 & 0,285 & 0,000 \\
\hline Routine & $-0,038$ & 0,000 & $-0,031$ & 0,000 & $-0,039$ & 0,000 & $-0,024$ & 0,000 \\
\hline Stress & $-0,045$ & 0,000 & $-0,061$ & 0,000 & $-0,049$ & 0,000 & $-0,060$ & 0,000 \\
\hline Motivation & 0,593 & 0,000 & 0,625 & 0,000 & 0,595 & 0,000 & 0,628 & 0,000 \\
\hline Confidence & 0,311 & 0,000 & 0,320 & 0,000 & 0,309 & 0,000 & 0,299 & 0,000 \\
\hline Qualific. Match & 0,385 & 0,000 & 0,377 & 0,000 & 0,379 & 0,000 & 0,382 & 0,000 \\
\hline Training & 0,328 & 0,000 & 0,255 & 0,000 & 0,335 & 0,000 & 0,316 & 0,000 \\
\hline Services & 0,082 & 0,000 & - & - & - & - & - & - \\
\hline Trade and Repair & - & - & 0,099 & 0,000 & - & - & - & - \\
\hline Accomodation... & - & - & $-0,049$ & 0,000 & - & - & - & - \\
\hline Transport... & - & - & 0,184 & 0,000 & - & - & - & - \\
\hline Financial and ... & - & - & 0,192 & 0,000 & - & - & - & - \\
\hline Real State... & - & - & 0,093 & 0,000 & - & - & - & - \\
\hline Public Admin. & - & - & 0,271 & 0,000 & - & - & - & - \\
\hline Education & - & - & 0,490 & 0,000 & - & - & - & - \\
\hline Human Health... & - & - & 0,165 & 0,000 & - & - & - & - \\
\hline Personal Services... & - & - & $A$ & - & - & - & - & - \\
\hline $\begin{array}{l}\text { Cox y Snell } \\
\text { Nagelkerke } \\
\text { McFadden }\end{array}$ & $\begin{array}{l}0,32 \\
0,32 \\
0,10\end{array}$ & & $\begin{array}{l}0,31 \\
0,32 \\
0,10\end{array}$ & & $\begin{array}{l}0,32 \\
0,32 \\
0,10\end{array}$ & & $\begin{array}{l}0,30 \\
0,311 \\
0,096\end{array}$ & \\
\hline
\end{tabular}

A. Reference category.

Source: Own elaboration from ECVT-2007. MTIN.

Services include a great heterogeneity of activities in term of job satisfaction (model 2). Working in Education and Public Administration direct to a higher job satisfaction, once we have control effect that introduce job satisfaction components. We get the contrary conclusion to Accommodation and Food Activities Services, and Trade and Repair, with low and negative coefficients. Then, we can establish that job satisfaction in services activities show deep differences. 


\section{FI NAL REMARKS.}

T he interest of analysis carried out has been to study the quality of job from a sectoral perspective. Our target has been double. On one hand, to determine until point can be accepted or not the hypothesis of which the services activities freq are linked to jobs with worse quality; so, in this context, the processes of terciarisation are constituted as one of factor to explain the decreasing of job quality levels. Of other one, to find out if the sector services can be considered of homogeneous from a job quality perspective or if, on the contrary, the analysis by braches has sense from the labour existing heterogeneity in qualitative terms.

Focusing on the Spanish case, and using information of the Spanish Labour Conditions Survey (ECVT-2007), the paper has adopted a double perspective to measure the quality of job: objective and subjective ones. From an objective perspective, there have been analyzed the characteristics associated with the jobs by the estimation of a synthetic index of quality of job. From the subjective perspective, the paper has tackled the study of the job satisfaction brought by the workpeople. Using this information, different probit models have been estimated arranged with that to analyze the sectoral differences existing by economic sectors.

The developed of theses analyses allow affirming, first of all, that the services do not collaborate in a general way at minor relative levels of quality of employment. Attending on the characteristics of jobs, the services do not obtain worse results than others, getting even a quality index of job lightly higher to the associate to the industrial employment. From the subjective perspective, the employment of the services are those who bring, in average terms, great levels of job satisfaction, so much general as for each of the considered components. The econometric analyses confirm these results, so that it turns out to be more probable to reach a high job satisfaction working at services.

Nevertheless, big disparities exist in the job quality inside the sector services. In this sense, the activities of Financial and Insurance Services and Education are those who present employments with higher quality to respects others service sectors. On the contrary, Personal Services and Household as Employer and Transport, Storage and Communications contain employments with lower qualitative value with regard to other tertiary branches. Analysis points out that these results are observed in terms of objective as well subjective term. Also, it are observed that different tertiary activities are related in a quite heterogeneous way to each of the components considered in the analysis of the job quality, so that notable differences exist as for the explanatory rules of the job quality. 
Although the analysis of the satisfaction has allowed establishing that the employees into service sector usually present a higher level of job satisfaction, its determinants are not different in the tertiary sector with regard to the rest of jobs. In this sense, the biggest differences in terms of the job satisfaction take place in base of labour aspects related to the holydays, the stability and the no wage earnings.

Thus, the workers of the services share with those of rest of sectors of activity the determinants of their perception of the quality of their employment. Tertiary and not tertiary workers share opinion about the characteristics and elements of his work that are more relevant in terms of his job satisfaction. The differences, therefore, are sustained in the fact that the services present in major measurement than other economic activities some of these characteristics. The observed differences into job satisfaction are sustained rather on differences in the characteristics and condition of jobs than worker's perceptions. 


\section{REFERENCES}

AHN, N. (2005). "Factors Affecting Life Satisfaction among Spanish Workers: Relative Importance of Wage and Others Factors". Ponencia presentada en las VI Jornadas de Economía Laboral. Alicante.

AHN, N. y GARCÍA, JR. (2004). "Job Satisfaction in Europe". Documento de Trabajo de FEDEA, 2004-11. Madrid.

BONHOMME, S. y JOLIVET, G. (2005). "The Pervasive Absence of Compensating Differentials". Documento de trabajo no 2005 28, Institut National de la Statistique et des Etudes Economiques.

CLARK, AE. (2005) "Your Money or Your Life: Changing J ob Quality in OECD Countries" Institute for the Study of Labor (IZA) IZA Discussion $\quad$ Papers $\quad$ №: 1610. ftp://repec.iza.org/RePEc/Discussionpaper/dp1610.pdf

COMISIÓN EUROPEA (2008). Comunicación de la Comisión al Consejo, al Parlamento Europeo, al Comité Económico y Social Europeo y al Comité de las Regiones. Agenda social renovada: oportunidades, acceso y solidaridad en la Europa del siglo XXI. Luxemburgo, COM (2008).

DUCATEL, k. (1994). Employment and Technical Change in Europe. Work Oganization, Skills and Training. Edward Elgar.

EUROPEAN COMMISSION (2009). Employment in Europe 2008. Bruxelas.

FAGERBERG, J. (1996). "Technology and Competitiveness". Oxford Review of Economic Policy, 12,3.

FAGERBERG, J., SRHOLEC, M. y KNELL, M. (2004). "The Competitiveness of Nations. The Second Globelics Conference. Beijing. China.

GREEN, F. (2006) "Demanding work - the paradox of job quality in the affuent economy" Princeton University Press.

HAMERMESH, DS. (2001). "The changing distribution of job satisfaction". J ournal of Human Resources, 36, 1,-30.

HERNANZ, V. y TOHARIA, L. (2004). “Do Temporary Contracts I ncrease Work Accidents? A microeconometric comparison between I taly and Spain". Documento de Trabajo de FEDEA, 2004-2. Madrid. 
HOUSEMAN, SH. (1995) "J ob Growth and the Quality of J obs in the U.S. Economy". W.E. Upjohn Institute for Employment Research in its series Staff Working Papers, number 95-39. August. http://www.upjohninstitute.org/publications/wp/95-39.pdf

IGLESIAS, C., LLORENTE, R. y DUEÑAS, D. (2009). “La expansión de los servicios y la transformación del empleo en España". Papeles de economía Española, 120, 28-43.

MAROTO, A. y CUADRADO, JR. (2006). La productividad en la economía española. Instituto de Estudios Económicos. Madrid.

TOHARIA, L. (dir.) (2005). El problema de la temporalidad en España: un diagnóstico. Ministerio de Trabajo y Asuntos Sociales. Madrid.

TOHARIA, L. y CAPRILE, M. (2006). “EI Indicador de Qualitat del Mercat de Treball en España". Anuari Sociolaboral de la UGT de Catalunya - 2005 - Monogràfies. Barcelona, 2006.

MTAS (2005). Más y mejor empleo en un nuevo escenario socioeconómico. Por una flexibilidad y seguridad laborales efectivas. Ministerio de Trabajo y Asuntos Sociales. Madrid.

WARR, PB. (1999) "Well-being and the workplace" en Kahneman, D., DIENER. E. y SCHWARZ, N. (eds.) Wel-Beinig: The Foundation of Hedonic Psychology. New Cork. Rusell Sage Foundation. 
AnNeX

TABLE A. 1.

Employment Sectoral Classification. Definitions.

\begin{tabular}{|c|c|}
\hline Sector / Branches & CNAE-94 two digits codes \\
\hline Agriculture & $01-05$ \\
\hline Industry & $10-41$ \\
\hline Construction & 45 \\
\hline Services & $50-99$ \\
\hline 1 Trade and Repair & $50,51,52$ \\
\hline 2 Accommodation and Food Activities Services & 55 \\
\hline 3 Transport, Storage and Communications & $60,61,63,64$ \\
\hline 4 Financial and Insurance Services & $65,66,67$ \\
\hline 5 Real State and Business Services & $70,71,72,73,74$ \\
\hline 6 Public Administration & 75 \\
\hline 7 Education & 80 \\
\hline 8 Human Health and Social Work Activities & 85 \\
\hline 9 Personal Services and Household as Employer. & $90,91,92,93,94,95,96,97,98,99$ \\
\hline
\end{tabular}

Source: Own elaboration from CNAE-94. 


\section{AUthORS}

\section{Carlos I glesias Fernández}

Director of Labor Economic Department (IAES) and Lecturer on Applied Economic (University of Alcalá). His main research lines are focused on economic analysis of labour market, the labour situation of women, tertiarization, occupational change, regional economic with especial reference to the region of Madrid and labour implication of immigration (carlos.iglesias@uah.es).

\section{Raquel Llorente Heras}

Researcher at Labor Economic Department (IAES). Lecturer on Economic Theory (University Autónoma de Madrid). She stress her research interests about the study and analysis of labor market, the labor segmentation, the European labor market and the economic analysis of immigration.

\section{Diego Dueñas Fernández}

Lecturer on Theory Department (University of Alcala) is also researcher at Labor Economic Department of IAES. His work are especially focused on study labor market from a gender perspective and economic implication of immigration. 